\title{
ANALYZING PATIENT SATISFACTION WITH REGARDS TO PROVISION OF FREE MEDICINES IN KHYBER PAKHTUNKHWA PAKISTAN
}

\author{
Neelam Farid', Mussawar Shah², Akhtar $\mathrm{Ali}^{2}$, Dawood Jan ${ }^{3}$ \\ ${ }^{1}$ Department of Rural Sociology, International Islamic University, Islamabad - Pakistan \\ ${ }^{2}$ Department of Rural Sociology, Agricultural University, Peshawar - Pakistan \\ ${ }^{3}$ Department of Management Sciences, Agricultural University, Peshawar - Pakistan
}

\begin{abstract}
Objective: To measure the association between provision of free medicines and patient satisfaction with regard to new health policy.

Materials and methods: A total of 384 sampled respondents (admitted patients, Male/Female) who visited the OPD for surgical and medical components were selected through random sampling technique from three public teaching hospitals namely, Khyber Teaching Hospital, Hayatabad Medical Complex and Lady Reading Hospital in district Peshawar Khyber Pakhtunkhwa respectively. A conceptual framework consisted of independent variable namely provision of free medicines and a dependent variable patient satisfaction was tabulated and analyzed through chi-square test statistics. The multi-variate analysis of the study intimated a non-significant association between patient satisfaction and provision of free medicines controlling family type and it was found a non-spurious relationship while comparing at bi-variate level.
\end{abstract}

Results: The findings revealed that any health policy with provision of special attention to patients by taking along the relevant stakeholders does yield the desired results. All these provisions may include the services with a strong mechanism of monitoring, evaluation based on reward and punishment.

Conclusion: At bi-variate analysis, both dependent and independent variable was indexed and a significant association was found between provision of free medicines and patient satisfaction.

Key words: Provision of free medicine, Patients Satisfaction, Age, Family Type

This article may be cited as: Farid N, Shah M, Ali A, Jan D. Analyzing patient satisfaction with reaards to provision of free medicines in Khyber Pakhtunkhwa Pakistan. J Med Sci 2021 January;29(1):42-47

\section{INTRODUCTION}

Access to essential medicine is imperative across the world and a well-functioning health care system needs availability of affordable, appropriate and quality of essential medicine as evident from past experiences which could lonely save 10 million lives both in Africa and Asia'. However, it's a challenging factor especially in low and middle income countries ${ }^{2}$. Although, the data can be found in fragmented form, low to middle income countries (LMICs) has reported that essential medicine availability is only $35 \%$ in public sectors ${ }^{3}$. Accordingly, World Health Organization (WHO) has affirmed that $68 \%$ people have no access to essential drugs in India ${ }^{4}$ and this enforces

\section{Correspondence}

Neelam Farid

Department of Rural Sociology, International Islamic

University, Islamabad - Pakistan

Email: neelam.farid@iiu.edu.pk

Cell: +92-333-9218646

Date received: $27-10-2020$

Date revised: $\quad 02-01-2021$

Date accepted: $02-02-2021$ public for out-of-pocket expenses for life saving drugs 5 . Nearly $90 \%$ public has to purchase medicine through outof-pockets payments (OOP) in the developing countries ${ }^{2}$ including India where $80 \%$ of public has to buy through OOP's ${ }^{6}$.

Access to free of cost essential medicines is a critical component of universal health coverage. This is being considered as a key intervention in Government of India's proposed National Health Assurance Mission in 20147 .Ensuring availability of free essential medicines significantly reduces the burden on private OOP expenditures. Moreover, it provides financial risk protection to population, most vulnerable to pay catastrophic health expenditures ${ }^{8}$. Every Indian state follows an independent mechanism of procurement of medicines. Various drug procurement models have been implemented for achieving the goals of universal health coverage. This has resulted in lower price and better availability of medicines through efficient supply chain management ${ }^{9,10}$. Tamil Nadu follows a mixed procurement system ( $80 \%$ centralized and $20 \%$ decentralized) whereas in Kerala it is completely centralized, for 
Analyzing Patient Satisfaction With Regards To Provision Of Free Medicines In Khyber Pakhtunkhwa Pakistan.

acquiring medicines. Moreover, the procurement systems in both the states are completely autonomous with minimal interference of state government. The governance structures created in the two states (Punjab and Haryana) are also very similar to the models followed in Kerala and Tamil Nadu. This has also led to similar processes being followed for inviting the suppliers, pricing, selection of essential medicines, setting up of distribution channels etc ${ }^{9}$. In Pakistan, the frequency of government expenses on health at provincial level including rural and urban areas while applying bio impedance analysis (BIA) methodology evaluated in-depth trends of access to health facilities and spending on health care in Pakistan including discrimination in the utilization of health care resources and service provision by the government. The consequences revealed rural areas are the most deprived and disadvantaged regions regarding the provision of health care facilities. Thus, expenditures in rural areas are wide regressive; whereas, only preventive measures are progressive in $\mathrm{Pa}$ kistan's health care sectors. Public health expenditure is pro-rich in Pakistan ${ }^{11}$.

Additionally, shortages and non-availability of fundamental drugs is a prevailing enigma in Pakistan public health sectors. This reason enforces public to contact private sectors instead of public health sector. There is no transparency and public has to receive the prescription according to physician from his mentioned pharmacy. A minor ratio of public has approach and access to health insurance and medicine costs. So it is evident that most of the medicine cost is out of pocket for the population who are graphed below the poverty level ${ }^{12}$. Other side, Chief Minister has ordered to health sector to ensure the provision of free of cost medicines in health sectors ${ }^{13}$. Conforming to this, KP Public Health sector has spent over one billion on the provision of free treatment to the public under the Sehatlnsaf Card Program, commenced in Jan 2017 and it will cover 150 million deserving people all across the province ${ }^{14}$.

Medical charges and high costs affects feeble mass, affects their financial decisions, and pay out of pockets payments, and irritate them even for their life saving drugs. Medicinal cost affects patients' management behavior, intensify disease, use substandard medicines, dose mutation, and will-impoverish for treatment. Communication gap add to the fuel, including paramedic and professional attitudes also provision of insufficient information programs multiply in Patients complications and recline their access to free of cost medicines ${ }^{15}$. All these mistaken premises might cause in epidemic mortality and threaten fair distribution of health care facilities ${ }^{16}$. Relationship between income and forgone are directly proportional to health, thus the cost barriers not only hindrances in access to health care but it also affects the psyche of patients ${ }^{19}$. Due to the prevailing mismanagement \& miss-governance; frugalities in drug supply and equipment non-availability, spoilage of drugs, and misuse of facilities as well as communication gap deny public of health care facilities ${ }^{20}$. Pharmaceuticals entice professionals for corruption which in turn intrudes in the system ${ }^{21}$. This study was conducted to find out patient satisfaction with regard to provision of free medicines to the public of Khyber Pakhtunkhuwa province.

\section{MATERIAL AND METHODS}

A total of 384 sampled respondents (admitted patients, Male/Female) who visited the OPD for surgical and medical components were selected through random sampling technique from the three public teaching hospitals namely, Khyber Teaching hospital, Hayatabad medical complex, and Lady reading hospital in district Peshawar Khyber Pakhtunkhwa, respectively. Bivariate and multivariate analysis was carried out and a spurious and non-spurious relation was ascertained through the application of chi-square test.

\section{RESULTS}

The results regarding provision of free medicines showed that $48.4 \%$ of the respondents disagreed that human right act of essential drug provision is strictly ensured in Pakistan. Sixty three (63\%) of the respondents opined that public has access to essential medicines without any bias at primary level. Majority (59.4\%) of the respondents agreed that cheap prices of medicines are offered to public in Pakistan whereas $49.7 \%$ disagreed about the provision of essential medicines at free of cost to the public, while (38\%) argued that those medicines which are available at hospital are provided and some may be barrowed. Majority $(71 \%)$ of the respondents agreed that high drugs expenses affect public access to appropriate health care. About $61.2 \%$ of patients were of the opinion that high cost of standard medicines compels people to use substitute and substandard medicines. Mediocre community faces difficulties in access to essential drugs was supported by $(48.7 \%)$ of the respondents. Moreover, $(75 \%)$ of the respondents that mostly market offers bigotry prices of essential drugs.

Majority (84.4\%) of the respondents agreed with the statement that in Pakistan approach of middle class to life saving is nothing but a nightmare. Around $58.3 \%$ respondents agreed that lack of proper information about drug utilization hampers the treatment of patients, (32.8\%) disagreed. This information is indicative of the fact that medicine companies have a vivid monopoly pertaining to regulating and controlling the drug prices. Majority (63.3\%) respondents were agreed that non registration of pharmacies leads to substandard medicines. Majority $(70 \%)$ of the respondents agreed that nonprofessional attitude of drug companies lift the flow of benefit to other stakeholders rather patients. Majority $(41 \%)$ agreed that provision of medicines is ensured based on revenue gen- 
Analyzing Patient Satisfaction With Regards To Provision Of Free Medicines In Khyber Pakhtunkhwa Pakistan.

eration rather than requisition.

The association between independent variables and dependent variable was determined with the help of chi square test. Table 1 shows association of provision of free medicines with patient satisfaction. Table 2 shows the influence of age grades regarding the association between patient satisfaction and provision of free medicines, indicated a non- significant $(P=0.154)$ for the respondents with the age group till 25 years. Furthermore, the association between the age groups between 25-35 years was also found a non- significant (0.907). Based on the above results, regarding the age of the respondents, the relationship between patient satisfaction and provision of free medicines was found non- spurious for all categories as results prevailed at bi-variate level. Similarly, the association was found non-significant $(P=0.323)$ and spurious for the age group 55-65 years. Similarly, a spurious and nonsignificant $(P=0.305)$ was also found for the age group above 65 years. Thus, in a nutshell, significant negative association was observed between patient's satisfaction and free of cost medicine provision at public health sectors evidently reveals the lack of quality health services.

Table 3 disclosed the association between patient's satisfaction and provision of free medicines. A non-significant association $(P=0.078)$ was observed between patient's satisfaction and free of cost medicine provision. In addition, a non-significant $(P=0.219)$ association was found between patient's satisfaction with provi-

Table 1: Association between Provision of Free Medicine and Patient Satisfaction

\begin{tabular}{|c|c|c|c|}
\hline s. & \multicolumn{2}{|l|}{ Variables } & Chi Square \\
\hline 1 & $\begin{array}{l}\text { Human right act of es- } \\
\text { sential drug provision }\end{array}$ & \multirow{4}{*}{$\begin{array}{l}\text { Provision } \\
\text { of free } \\
\text { medicine }\end{array}$} & $\chi^{2}: 12.034(.443)$ \\
\hline 2 & $\begin{array}{l}\text { Access to essential } \\
\text { medicine at primary } \\
\text { level }\end{array}$ & & $\chi^{2}: 11.368(.498)$ \\
\hline 3 & $\begin{array}{l}\text { Medicines with cheap } \\
\text { prices are offered }\end{array}$ & & $\chi^{2}: 33.235(.001)$ \\
\hline 4 & $\begin{array}{l}\text { Essential medicine are } \\
\text { provided free of cost }\end{array}$ & & $\chi^{2}: 12.716(.176)$ \\
\hline 5 & $\begin{array}{l}\text { High Drugs expenses } \\
\text { affect public access }\end{array}$ & \multirow[t]{6}{*}{$\begin{array}{c}\text { Patient } \\
\text { satisfaction }\end{array}$} & $\chi^{2}: 16.933(.152)$ \\
\hline 6 & Standard Drug prices & & $\chi^{2}: 16.694(.161)$ \\
\hline 7 & $\begin{array}{l}\text { Mediocre community } \\
\text { confronts imped- } \\
\text { iments to access } \\
\text { essential drugs }\end{array}$ & & $\chi^{2}: 33.250(.004)$ \\
\hline 8 & $\begin{array}{l}\text { Market offers bigotry } \\
\text { prices of essential } \\
\text { medicine }\end{array}$ & & $\chi^{2}: 5.511(.788)$ \\
\hline 9 & $\begin{array}{l}\text { Approach to life-sav- } \\
\text { ing drugs }\end{array}$ & & $\chi^{2}: 13.193(.154)$ \\
\hline 10 & $\begin{array}{l}\text { Lack of information } \\
\text { provision }\end{array}$ & & $\chi^{2}: 13.433(.338)$ \\
\hline
\end{tabular}

Table 2: Age wise association between Provision of free medicine and Patients satisfaction

\begin{tabular}{|c|c|c|c|}
\hline \multicolumn{3}{|c|}{ Variables } & \multirow{2}{*}{$\begin{array}{c}\begin{array}{c}\text { Chi Square } \\
\text { P-Value }\end{array} \\
\begin{array}{l}\chi^{2}=.696 \\
P=0.154\end{array}\end{array}$} \\
\hline \multirow[t]{6}{*}{ Age Group } & up to 25 & \multirow[t]{3}{*}{$\begin{array}{l}\text { Provision of } \\
\text { free medicine }\end{array}$} & \\
\hline & 25.1-35 & & $\begin{array}{l}\chi^{2}=.064 \\
P=0.907\end{array}$ \\
\hline & $35.1-45$ & & $\begin{array}{c}\chi^{2}=.696 \\
P=0.339\end{array}$ \\
\hline & $46.1-55$ & \multirow[t]{3}{*}{$\begin{array}{c}\text { Patient } \\
\text { satisfaction }\end{array}$} & $\begin{array}{l}\chi^{2}=1.000 \\
p=0.302\end{array}$ \\
\hline & $55.1-65$ & & $\begin{array}{c}\chi^{2}=.833 \\
\mathrm{P}=0.323\end{array}$ \\
\hline & Above 65 & & $\begin{array}{l}\chi^{2}=1.000 \\
P=0.305\end{array}$ \\
\hline
\end{tabular}

Table 3: Family wise Association between the Provision of free medicine and patient satisfaction

\begin{tabular}{|c|c|c|c|}
\hline \multicolumn{3}{|c|}{ Variables } & $\begin{array}{c}\text { Chi Square } \\
\text { P-Value }\end{array}$ \\
\hline Family Type & Nuclear & $\begin{array}{c}\text { Provision of } \\
\text { medicine }\end{array}$ & $\begin{array}{c}\chi^{2}=.847 \mathrm{P} \\
=0.078\end{array}$ \\
\cline { 2 - 4 } & Joint & $\begin{array}{c}\text { Patient } \\
\text { Satisfaction }\end{array}$ & $\begin{array}{c}\chi^{2}=.461 \mathrm{P} \\
=0.219\end{array}$ \\
\hline
\end{tabular}

sion of free medicines while controlling family type, but it was found a non-spurious relationship while comparing at bi-variate level. By comparing these results with the level of significance at bi-variate level, it was found significant $(P=0.02)$ and non-spurious relationship with the aforementioned variables.

\section{DISCUSSION}

In our study, majority of the respondents were disagreed that human right act of essential drug provision is strictly ensured in Pakistan. This is supported by the findings that access of masses to essential medicines is a part of the human right to health. In Pakistan People do not have access to good quality and affordable medicines $^{22}$. Sixty three (63\%) of the respondents opined that public has access to essential medicines without any bias at primary level. The data is contrary to the findings that the provision of essential medicines to the masses does not ensure equitable access ${ }^{23}$. Majority of the respondents were agreed that cheap prices of medicines are offered to public in Pakistan. This was supported with the findings that patient's non satisfaction with the provision of medicines was their non-availability at hospital pharmacy ${ }^{24}$. Medicines availability at public hospitals is a very challenging task and patients are not able to get the required medicines from hospitals and ultimately, they borrowed the prescribed medicines from outside ${ }^{25}$. These results disclosed that pharmaceutical have their major focus on 
profiting, rather to extend support to patients in economic terms and mobility standard. These findings are consistent by the study that globally, pharmaceuticals are focusing on earning, and little attention is paid to prevent the disease through their medicines ${ }^{22}$. Moreover, most of the essential drugs are not provided to the patients as per the prescribed ways of distribution which results in lack of the essential commodities in the hands of few thus leading to exploitation of poor's in the shape of unjust distribution and more earnings for these pharmaceutical ${ }^{26,27,28}$.

The results of chi square test show a non-significant association between human right act of essential drug provision ensured in Pakistan and patients satisfaction. These are consistent with the findings that essential medicines which are not usually affordable, is the pre-requisite on the part of government in the study area. This was also repugnance by the study that international public health organization has placed a top priority on the provision of effective treatment based on unabated supply of the required medicines ${ }^{22}$.

A non-significant association was found between public having access to essential medicine at primary level without bias and patient satisfaction. It could be attributed to the study that due to high prices of medicines and treatment, majority of the poor perceives and expects that the cost of medicine and treatment should be borne by the hospital authority. But the situation is not as much satisfactory as is claimed. A common opinion prevailed in the health care department is concerned with the issue of corrupt practices like hoarding, artificial surge in price and shortage which have hindered the supply chain and has resultantly affected the hospital management efficiency. Consequently, hospitals provide only cheaper medicines and costly medicines are available outside the hospitals. This has made people to deduce that there is scarcity of medicine in the hospitals ${ }^{29}$.

A highly significant association was found between medicines with cheap prices offered to public in $\mathrm{Pa}$ kistan and patients satisfaction. These findings revealed that cheap prices of medicines are maintained in hospitals across Pakistan. These could be attributed to a vibrant national health policy that conspicuously defined and explained the domain of each stakeholder in order to attain maximum efficiency. When a patient evaluates the providers and services of health care, their satisfaction can be marked as patient's satisfaction criteria. Performance and health care programs can be effectively measured by Patients satisfaction ${ }^{30}$. These findings revealed that cheap prices of medicines are maintained in hospitals across $\mathrm{Pa}$ kistan. The index propounded with reference to community health center shows that $(96 \%)$ patients are satisfied and $(4 \%)$ of the patients are not satisfied with the services of pharmacy. However, the attributed fact for dissatisfaction was that medicines were not available at pharmacy or the patient did not purchase from $\mathrm{CHC}$ (Community Health Center) pharmacy ${ }^{25}$.

A non-significant association was found between essential medicines which are mostly provided free of cost at public sectors hospitals and patients satisfaction. Accordingly, global inequities in accessibility to medicines exist between rich and poor countries because of market and government failures as well as huge income differences. The study indicates that the local (study area) prospects are not free from these in Pakistan. Incidentally, multifarious strategic steps are to be taken to fill the medicine gap at global level22. A non-significant association was also found between high drugs expenses affect public access to appropriate health care and patient's satisfaction. A non-significant association was also found in record of expenditure of medicines, France government and its national health care services never explored about the percentage of expenditure for costly medicines that are consumed in hospitals ${ }^{31}$.

Similarly, non-significant association was also found between the standard drug prices enforce public for substitute and substandard medicines and patient's satisfaction. A highly significant association between mediocre communities that confronts impediments to access essential drugs and patient's satisfaction. Reduction in disability and death from many diseases can only be made possible by improving the strategies to access good quality treatment. It is the part of those organizations that work for human rights to provide necessary medicine to general public. It is also to make sure that general public avails all the opportunities in order to get effective health results at international level22.

However, non-significant association was explored between market offers bigotry prices of essential medicines or drugs and patients satisfaction. Similarly, non-significant association was found between approaches to life-saving drugs is a nightmare for feeble and middle class and patients satisfaction. An investigation conducted in the KPK province on part of the health care services in 2002, the figures show that a larger part of expenditure on drugs and medicine indicate $90 \%$ privately whereas only $60 \%$ of drugs and medicine is salaried by the households. Moreover, non-significant association was also found in lack of information provision regarding drug utilization hampering proper treatment of patients and patient's satisfaction $^{32}$.

Poorly trained Pharmacy staff is a crucial issue for managing and supplying medicines at health center service delivery. Different public health facilities e.g. medicine management, supply chain function, flow of logistics information, access to essential medicines improve when availability of medicines improves ${ }^{33}$. Non-significant associations were also found between non-professional attitudes of drugs companies lifting the flow of benefits in form of 
other stakeholders rather than patients and patient's satisfaction. Likewise, non-significant association was found between provision of medicine which is ensured on the basis of revenue generation instead of requisition and patients satisfaction. Another study reveals that patients and their care takers are not satisfied ${ }^{34}$.

\section{CONCLUSION}

At bi-variate analysis, both dependent and independent variable was indexed and a significant association was found between provision of free medicines and patient satisfaction.

\section{REFERENCES}

1. Zarocostas J. Better Access to Medicines Could Save 10 Million Lives a Year, Says UN expert. BMJ. 2007: 335635.Doi: 10.1136/bmj.39349.706782.DB.

2. WHO. World Health Organization. Equitable Access to Essential Medicines: A Framework for Collective Action. Geneva: World Health Organization; 2004.

3. Cameron A, Ewen M, Ross-Degnan D, Ball D, Laing R. Medicine Prices, Availability, and Affordability in 36 Developing and Middle-Income Countries: A Secondary Analysis. Lancet, 2009;37:240-249.Doi:10.1016/S01406736(08)61762-6.

4. WHO. World Health Organization: The World Medicines Situation. Geneva: World Health Organization; 2004.

5. Oberoi S, Oberoi A. Pharmacy Economics Guidelines: The Need of Hour for India. International Journal of Pharmaceutical Investigation. Int J Pharma Investig. 2014; 4:109-111. Doi: 10.4103/2230-973X.138338.

6. Ministry of Health and Family Welfare $\{M O H F W\}$. Government of India: National health accounts India (20042005) New Delhi: World Health Organization; 2009.

7. MOHFW. Rolling Out of National Health Assurance Mission. New Delhi: Press Information Bureau, Ministry of Health and Family Welfare, Government of India; 2014.

8. HLEG. Book High Level Expert Group Report on Universal Health Coverage for India. City: Planning Commission of India. High Level Expert Group Report on Universal Health Coverage for India. 2011.

9. Singh P, Tatambhotla A, Kalvakuntla R, Chokshi M. Understanding Public Drug Procurement in India: A Comparative Qualitative Study of Five Indian States. BMJ Open.2013;3: e001987.

10. TNMSC: Drug Procurement Policy- Tamil Nadu Medical Service Corporation. http://www.tnmsc.com/tnmsc/new/ html/Procurement\%20\&\%20Tender.php.

11. Muhammad Akram. International Institute of Islamic Economics International Islamic University, Islamabad and Faheem Jehangir Khan Pakistan Institute of Development Economics, Islamabad; Health Care Services and Government Spending in Pakistan, 2007.

12. Booklet of Drug Controls Organization, Available from: http://www.dcomoh.gov.pk/downloads/booklet.pdf.
13. Pakistan Today. KP CM Directs to Ensure Doctors Presence, Free Medicines at Hospitals. 2018 December 25.

14. Ashfaq Yusufzai. DAWN group of newspapers. Rs1 billion spent on Sehatlnsaf program; September, 2017.

15. Schafheutle El, Hassell K, Noyce PR, Weiss MC. Access to Medicines: Cost as an Influence on the Views and Behaviour of Patients. Health Soc Care Community. 2002;10(3):187-95.

16. Attaran A. How do Patients and Economic Policies Affect Access to Essential Medicines in Developing Countries? Health Aff (Millwood). 2004 May-Jun;23(3):155-66.

17. Hanlon P, Carlisle S, Hannah M, Lyon A, Reilly D. A Perspective on the Future Public Health Practitioner. Perspectives in Public Health, 2012; 132: 235-239. Doi:10.1177/1757913911412217.

18. Srivastava A, Avan I. Bilal, Rajbangshi P, Bhattacharyya S. Determinants of Women's Satisfaction with Maternal Health Care: A Review of Literature from Developing Countries. BMC Pregnancy and Childbirth. 2015; 15:97.

19. Carrión VG, Garrett A, Menon V, Weems CF, Reiss AL. Posttraumatic Stress Symptoms and Brain Function During a Response-Inhibition Task: An fMRI study in youth. Depression and Anxiety. 2008; 25:514-526.

20. Acker J. The Diseases, Illness and Patient: International Journal of Health and Development Africa.1998; 5(4); 195-206.

21. Sheikh T, Juanita $H$. Health service utilization in Pakistan" (pp. 1- 6), 2004.

22. Wiedenmayer K. Access to Medicines. Medicine Supply: Lessons Learnt in Tanzania and Mozambique. Basel: Swiss Agency for Development and Coorperation, 2004.

23. Bazargani YT, Ewen M, De Boe A, Leufkens HG, Mantel-Teeuwisse A. K. Essential Medicines Are More Available Than Other Medicines Around the Globe. PLoS One.2014; 9(2) :e87576.Doi: 10.1371/journal. pone.0087576.

24. Israr M, Awan N, Jan D, Ahmad N, Ahmad S. Patients' perception, views and satisfaction with community health center services at mardan district of Khyber Pakhtunkhwa. Am J Public Health Res. 2016 Apr 14;4(3):7987.

25. Hadley MB, Blum LS, Mujaddid S, Parveen S, Nuremowla S, Haque ME et al. Why Bangladeshi Nurses Avoid 'Nursing': Social and Structural Factors on Hospital Wards in Bangladesh. SocSci Med. 2007; 64 (11),66-77.

26. Akokuwebe ME, Adekanbi DM. Corruption in the Health Sector and implications for Service Delivery in Oyo State Public Hospitals. Ilorin Journal of Sociology. 2017; 9 (1); 200-217.

27. Gorter AC, Bellows B. Do Competitive Voucher Schemes Improve the Provision of Health Care to Underserved and/or Vulnerable Population Groups. Experiences from Nicaragua, India and Africa.2008.

28. Mackey TK, Liang BA. Combating Healthcare Corruption and Fraud with Improved Global Health Governance. BMC International Health and Human Rights.2012; 12(1), 23. 
Analyzing Patient Satisfaction With Regards To Provision Of Free Medicines In Khyber Pakhtunkhwa Pakistan.

29. Hussain MM, Raihan MMH. Patients' Satisfaction with Public Health Care Services in Bangladesh: Some Critical Issues. Malaysian Journal of Medical and Biological Research. 2015; 2(2), 115-126.

30. Dearmin J, Brenner J, Migliori R. Reporting on QI efforts for internal and External Customers. The Joint Commission Journal on Quality Improvement. 1995; 21(6), 277288.

31. Hawlik K, Devalière A. Access to High-priced Medicines in Hospital Settings in Europe: A Study in Four European Countries. Amsterdam: Health Action International. 2016.

32. Luoma M, Doherty J, Muchiri S, Baraga T, Hofler K, Maniscalco L, Ouma C, Kirika R, Maundu, J. Kenya Health System Assessment 2010. Bethesda, MD: Health Systems 20/20 project, Abt Associates Inc.

33. Lubinga JC, Clift SJ, Tuppurainen ES, Stoltsz WH, Babiuk S, Coetzer JA, Venter EH. Demonstration of Lumpy Skin Disease Virus Infection in Amblyommahebraeum and Rhipicephalus appendiculatus ticks using immunohistochemistry. Ticks Tick Borne Dis. 2014 Mar;5(2):11320. Doi: 10.1016/j.ttbdis.2013.09.010.

34. Hussain MM, Raihan MMH. Patients' Satisfaction with Public Health Care Services in Bangladesh: Some Critical Issues. Malaysian Journal of Medical and Biological Research.2015; 2(2), 115-126.
CONFLICT OF INTEREST: Authors declare no conflict of interest

GRANT SUPPORT AND FINANCIAL DISCLOSURE: NIL

\section{AUTHOR'S CONTRIBUTION}

Following authors have made substantial contributions to the manuscript as under

Farid N: Concept, study design, discussion, manuscript writing.

Shah M: Critical review, Interpretation of results.

Ali A: $\quad$ Planning of the study, Statistical analysis, Bibliography.

Jan D: $\quad$ Critical review, Manuscript writing.

Authors agree to be accountable for all aspects of the work in ensuring that questions related to the accuracy or integrity of any part of the work are appropriately investigated and resolved. 